Legacies of Struggle 



\section{Legacies of Struggle}

Conflict and Cooperation

in Korean American Politics

Angie Y. Chung

Stanford University Press

Stanford, California 
Stanford University Press

Stanford, California

(C)2007 by the Board of Trustees of the Leland Stanford Junior University. All rights reserved.

No part of this book may be reproduced or transmitted in any form or by any means, electronic or mechanical, including photocopying and recording, or in any information storage or retrieval system without the prior written permission of Stanford University Press.

Printed in the United States of America on acid-free, archival-quality paper

Library of Congress Cataloging-in-Publication Data

Chung, Angie Y., 1973-

Legacies of struggle : conflict and cooperation in Korean

American politics / Angie Y. Chung.

p. cm.

Includes bibliographical references and index.

ISBN 978-0-8047-5657-0 (cloth : alk. paper)-ISBN 978-0-8047-5658-7

(pbk. : alk. paper)

1. Korean Americans-Politics and government. 2. Korean Americans-Ethnic identity. 3. Korean Americans-Societies, etc.-Case studies. 4. Children of immigrants-United States-Political activity. 5. Children of immigrants-United States-Societies, etc.-Case studies. 6. Intergenerational relations-United States. 7. Elite (Social sciences) - United States. 8. Power (Social sciences) -United States. 9. Community life-United States. 10. United States-Ethnic relations. I. Title.

E184.K6C53 2007

$305.895^{\prime} 7073009045-\mathrm{dc} 22$

2007000343

Typeset by Thompson Type in 10/14 Minion 
To my parents, Connie and Ye Hyun, whose love and lives have inspired me to cross the generational divide 
